\title{
WATER QUALITY CONSIDERATIONS FOR THE CULTURE OF TROPICAL EDIBLE FROG (HOPLOBATRACHUS OCCIPITALIS) FROM TADPOLE STAGE TO FULL METAMORPHOSIS
}

\author{
M. K. Mustapha \\ moonstapha@yahoo.com
}

Department of Zoology, University of Ilorin,

University Road, Ilorin, 240003, Nigeria

Good water quality is necessary for artificial cultivation of frogs. There has not been a recommended value for water quality in frog culture.

This study was undertaken to determine the ranges of some water quality parameters for the culture of Hoplobatrachus occipitalis from tadpole stage to full metamorphosis. 180 tadpoles were distributed into 3 tanks each filled with 60 litre water and renewed through a flow-through system. Water quality parameters were measured for 16 weeks during which the tadpoles fully metamorphosed with only about $10 \%$ mortality. Results showed temperature ranged between 24.1 and $27.2^{\circ} \mathrm{C}, \mathrm{pH}$ 6.8-7.2. Conductivity varied between 240 and $280 \mu \mathrm{S} / \mathrm{cm}$, Total Dissolved Solids 161-188 mg/l, Alkalinity 225-200 mg/l, Calcium, Magnesium and Total Hardness were in the ranges of 80-100 $\mathrm{mg} / \mathrm{l}, 40-60 \mathrm{mg} / \mathrm{l}$ and $120-160 \mathrm{mg} / \mathrm{l}$, respectively. Phosphate and $\mathrm{Ni}$ trate varied between 0.3-0.8 and $0.8-1.3 \mathrm{mg} / \mathrm{l}$, respectively. Dissolved oxygen was between 6.2 and $6.9 \mathrm{mg} / \mathrm{l}$, while Ammonia ranged between $0.10 \mathrm{mg} / \mathrm{l}$ and $0.22 \mathrm{mg} / \mathrm{l}$. These ranges were good water quality values for the rearing of the species, because of the full metamorphosis of the frog and the low (10\%) mortality rate recorded in 16 weeks. The flow through system which allowed frequent change of water and the ground (borehole) water used for culture helped in achieving the good water quality in the tanks.

Keywords: EDIBLE FROGS, WATER QUALITY, TADPOLES, METAMORPHOSIS, CULTURE, FLOW-THROUGH, GROUND WATER

\section{ПАРАМЕТРИ ЯКОСТІ ВОДИ ДЛЯ ВИРОЩУВАННЯ ТРОПІЧНОЇ ЖАБИ ЇСТІВНОЇ (HOPLOBATRACHUS OCCIPITALIS) ВІД СТАДІЇ ПУГОЛОВКА ДО ПОВНОГО МЕТАМОРФОЗУ}

\author{
M. K. Mycmaфa \\ moonstapha@yahoo.com
}

Кафедра зоології, Університет Ілоріна,

Університетська дорога, Ілорін, 240003, Нігерія

Для штучного вирощування жаб необхідна належна якість води. Проте в наш час немає рекомендованих норм складу води для утримання жаб.

Проведено дослідження з метою встановлення допустимих меж коливання параметрів води для утримання жаб виду Hoplobatrachus осcipitalis від стадії пуголовка до формування зрілої особини. 180 пуголовків було розміщено у 3 акваріуми з проточною системою водопостачання, місткістю $60 \mathrm{л}$ кожен. Параметри якості води вимірювали впродовж 16 тижнів, протягом яких пуголовки пройшли повний метаморфоз. Смертність становила лише $10 \%$. Параметри води під час досліду коливались у межах: температура $24,1-27,2{ }^{\circ} \mathrm{C}, \mathrm{pH}$ 6,8-7,2, електропровідність 240-280 мкСм/см, загальний вміст твердих частинок 161-188 мг/л, лужність 225-200 мг/л, загальна жорсткість 120-160 мг/л, концентрація Кальцію 80-100 мг/л, Магнію 40-60 мг/л, фосфатів 0,3-0,8 мг/л, нітратів 0,8-1,3 мг/л, розчиненого кисню 6,2-6.9 мг/л, аміаку 0,10-0,22 мг/л. Такий діапазон показників якості води виявився придатним для виромування жаб иього виду, про що свідчить нормальний метаморфоз $і$ низька смертність (10\% \%а 16 тижснів). Проточна система водопостачання з використанням підземних вод зі свердловини забезпечила сприятливі умови для вирощування жаб.

Ключові слова: ЖАБА ЇСТІВНА, ЯКІСТЬ ВОДИ, ПУГОЛОВКИ, МЕТАМОРФОЗ, ВИРОЩУВАННЯ, ПРОТОЧНА СИСТЕМА ВОДОПОСТАЧАННЯ 


\title{
ПАРАМЕТРЫ КАЧЕСТВА ВОДЫ ДЛЯ ВЫРАЩИВАНИЯ ТРОПИЧЕСКОЙ ЛЯГУШКИ СЬЕДОБНОЙ (НOPLOBATRACHUS OCCIPITALIS) ОТ СТАДИИ ГОЛОВАСТИКА ДО ПОЛНОГО МЕТАМОРФОЗА
}

\author{
M. K. Mycmapa \\ moonstapha@yahoo.com
}

Кафедра зоологии, Университет Ілорина,

Университетская дорога, Ілорин, 240003, Нигерия

Для искусственного выращивания лягушек необходимо надлежащее качество воды. Однако в настоящее время нет рекомендуемых норм состава воды для содерэсания лягушек.

Проведено исследование с иелью определения допустимых пределов колебания параметров воды для лягушек вида Hoplobatrachus occipitalis от стадии головастика до формирования зрелой особи. 180 головастиков были помещены в 3 аквариумы с проточной системой водоснабжсения, вместимостью 60 литров каждый. Параметры качества воды измеряли в течение 16 недель, в течение которых головастики прошли полный метаморфоз. Смертность составила всего $10 \%$. Параметры воды во время опыта колебались в пределах: температура $24,1-27,2{ }^{\circ} \mathrm{C}, \mathrm{pH}$ 6,8-7,2, электропроводность 240-280 мкСм/см, общее содержание твердых частии 161-188 мг/л, щеелочность 225-200 мг/л, общая жесткость 120-160 мح/л, конщентрация кальиия 80-100 мг/л, магния 40-60 мг/л, фосфатов 0,3-0,8 мг/л, нитратов 0,8-1,3 мг/л, растворенного кислорода 6,2-6.9 мг/л, аммиака 0,10-0,22 мг/л. Такой диапазон показателей качества воды оказался пригодным для вырашивания лягушек этого вида, о чем свидетельствует нормальный метаморфоз и низкая смертность (10\% за 16 недель). Проточная система водоснабжения с использованием подземных вод из скважины обеспечила надлежащие условия для выращивания лягущек.

Ключевые слова: ЛЯГУШКА СЪЕДОБНАЯ, КАЧЕСТВО ВОДЫ, ГОЛОВАСТИКИ, МЕТАМОРФОЗ, ВЫРАЩИВАНИЕ, ПРОТОЧНАЯ СИСТЕМА ВОДОСНАБЖЕНИЯ

Frog culture/farming is becoming a promising and profitable venture especially in developing tropical countries of sub-Saharan Africa. This is due to the increasing demand of frog as alternative source of animal protein, the increasing cost of traditional sources of animal protein such as beef, chicken and fish as well as its competitive edge in terms of production, affordability and nutritive value over fish, beef and chicken. In later time, frog culture will overtake fish culture as a sustainable aquaculture industry.

However, the success of frog culture largely depends on the operational water quality of the pond where the frog is raised. This is even more pertinent as frogs though amphibious spend most of their life cycle in water. According to [14, 11] breeding frogs under artificial farm-like conditions have often failed. This is mainly due to inadequate considerations of the water quality of the farms. [3] had reported that successful rearing of tadpoles mainly depends on the water quality used in the culture.

Water quality considerations in frog ponds includes all physical, chemical, biological and aes- thetic factors of water that operate synergistically to maintain the survival and production of frogs. High quality water must be readily available to frogs during their breeding as their development or metamorphosis depend among other things the water quality of the pond. Most important water quality parameters in frog culture pond include temperature, dissolved oxygen, $\mathrm{pH}$, alkalinity, ammonia, nitrate, phosphate, calcium hardness, magnesium hardness, total hardness, transparency, conductivity, and total dissolved solids.

There has not been a standard or recommended value or range for good water quality in frog culture. This is because researches on water quality in frog culture are scarce. The few studies in this area include those of $[4,10,1,8,13]$.

The objective of this study was to determine the ranges of some water quality parameters for successful tropical edible frog (Hoplobatrachus occipitalis) culture from tadpole stage to full metamorphosis. This is with a view of establishing ranges of some physic-chemical factors and recommending same as standard for frog culture in ponds. 


\section{Materials and methods}

Experimental design. 180 Hoplobatrachus occipitalis tadpoles with average length and weight of $5.8 \mathrm{~cm}$ and $1.93 \mathrm{~g}$ respectively were obtained from a local fish farm pond in Ilorin, Nigeria during their breeding season. The tadpoles were transported in 3 open tanks, each containing 60 tadpoles that were filled with 60 litres of well oxygenated water of the pond early in the morning at a temperature of $21^{\circ} \mathrm{C}$ to the Laboratory of the Department of Zoology, University of Ilorin, Ilorin, Nigeria.

In the laboratory, the tadpoles were distributed into 3 experimental tanks measuring $1 \times 1 \times 0.2 \mathrm{~m}$ (length, width and depth) and labelled $\mathrm{T}_{1}-\mathrm{T}_{3}$, each containing 60 tadpoles. Each tank had 60-litre water capacity, well aerated, with water supply from borehole (ground water) and constantly renewed through a flow-through system. The tanks were covered with nets to prevent escape of the frogs during the rearing period.

Measurement of the water quality parameters was done weekly for 16 weeks during which the tadpoles grew and fully metamorphosed with only about $10 \%$ mortality in each tank. $50 \mathrm{ml}$ plastic water bottle was used for the collection of water samples for the analysis of the following water quality parameters: Alkalinity, calcium and magnesium hardness which were measured using colometric method, phosphate measured using amino acid method, nitrate measured by cadmium reduction method, ammonia measured using nessler method and dissolved oxygen measured by azide modification of winkler's method. All measurements were done according to [17] standard procedures. All the parameters were analyzed with the aid of Hanna Multiparameter Bench Photometer for Laboratories Model HI 83200-02. Temperature, pH, electrical conductivity and total dissolved solids were measured in situ in the tanks using Hanna Portable pH/ EC/TDS/Temp combined waterproof tester Model HI 98129. Triplicates water samples of the tanks were obtained and measured for all the chemical parameters, while $\mathrm{pH}$ and temperature, electrical conductivity and total dissolved solids measurements were also measured in triplicates in situ.

Statistical Analyses. GLM procedure of statistical analysis system 9.1.3 [15] was used to analyze the results. Weekly mean difference of each triplicate parameter was compared using two way ANOVA at $\mathrm{P}<0.05$ to see the variations due to weeks (temporal variations) and tanks (spatial variations).

\section{Results and discussion}

The mean weekly results of the water quality variables in each tank are presented in tables 1 , 2 and 3. The overall mean of all the water quality parameters for the culture of tropical edible frog (Hoplobatrachus occipitalis) from tadpole stage to full metamorphosis is shown in table 4. Temperature in the tanks ranged between 24.1 and $27.2^{\circ} \mathrm{C}$ with the lowest and highest recorded in week 1 and 16 respectively. There was no significant differences $(\mathrm{P}>0.05)$ in temperature variations among the 3 tanks, however, there was significant differences $(\mathrm{P}<0.05)$ in the temporal variations in the tanks. The overall mean of temperature measurements in the 3 tanks was $26.05{ }^{\circ} \mathrm{C}$. Temperature ranges for the best culture of tropical edible frog Hoplobatrachus occipitalis is between 24 and $28^{\circ} \mathrm{C}$, with the average being $26^{\circ} \mathrm{C}$. This temperature ranges has been reported by $[8,3,13]$ as ideal for the growth of frog tadpoles in ponds. This temperature which is ideal should be maintained during culture especially in tropical climate since growth of frogs is related to temperature [9].

$\mathrm{pH}$ variations was from the lowest of 6.8 recorded in the first week in all the tanks to the highest of 7.2 recorded in week 16 in all the tanks. There was no significant difference $(\mathrm{P}>0.05)$ in the spatial and temporal variations in the $\mathrm{pH}$ in the tanks. The overall mean $\mathrm{pH}$ recorded in the tanks was 6.99. Recommended $\mathrm{pH}$ ranges for culture is from slight acidity to slight alkalinity, with a range of 6.8 to 7.2 and an overall average of 6.9 (slight acidity). [6] reported $\mathrm{pH}$ values around 7.33, towards the alkaline range, [7] recommended mild acidity, while [16] suggested a $\mathrm{pH}$ range between 6.5 to 7.0 as ideal for frog culture.

Electrical conductivity (EC) varied between a minimum of $240 \mu \mathrm{S} / \mathrm{cm}$ recorded in week 1 in all the tanks and maximum of $280 \mu \mathrm{S} / \mathrm{cm}$ recorded in week 16 in tanks 1 and 3 respectively. There was no significant differences $(\mathrm{P}>0.05)$ in the variations of electrical conductivity in the 3 tanks, but, there was significant differences $(\mathrm{P}<0.05)$ in 


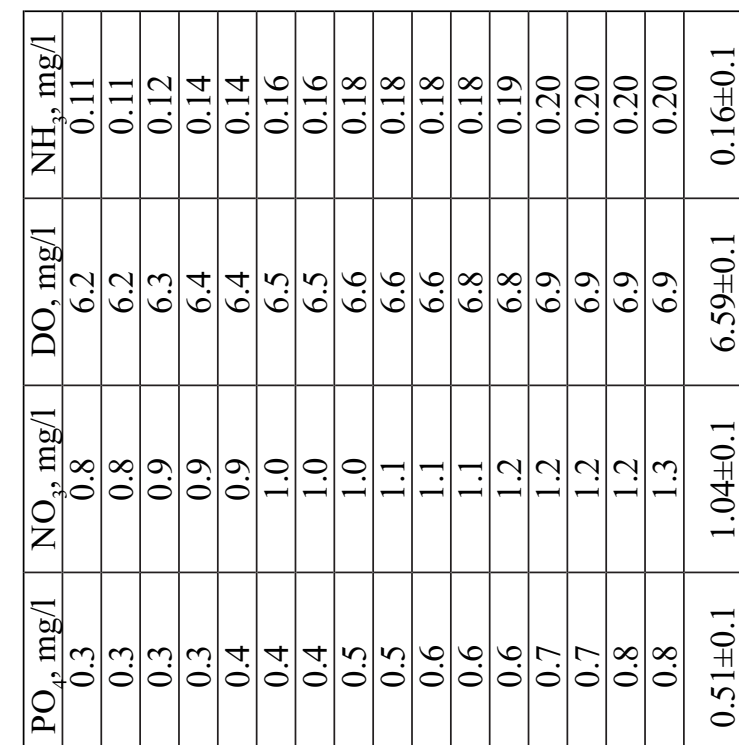

焉

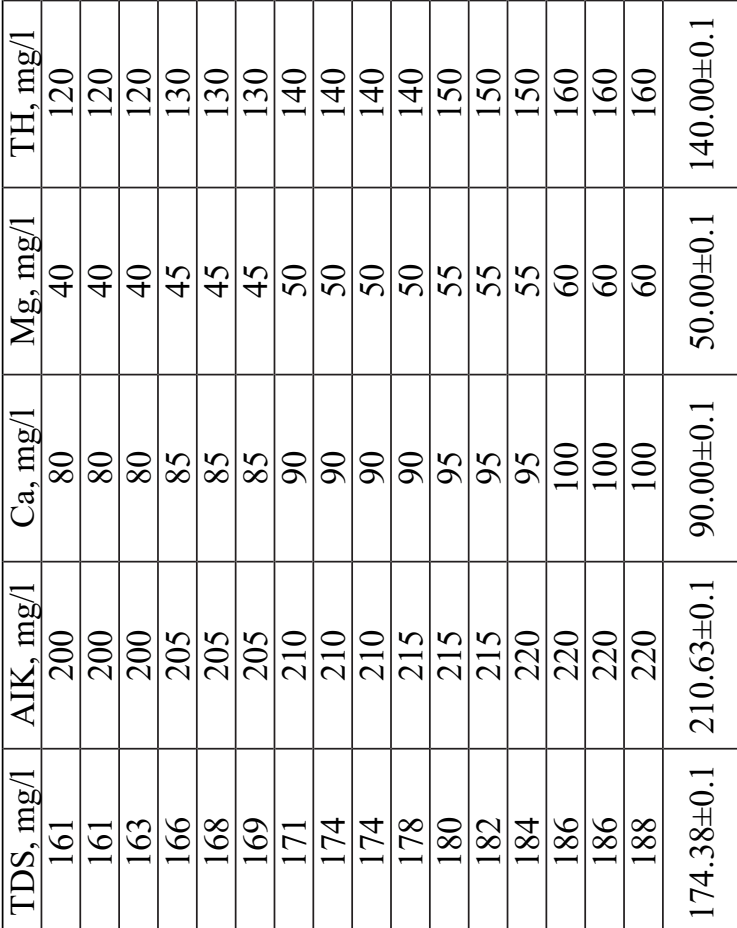

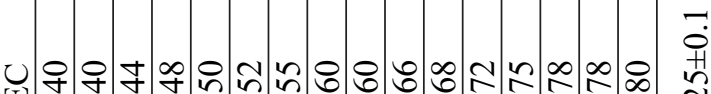

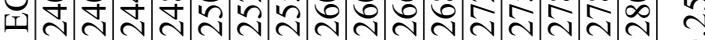

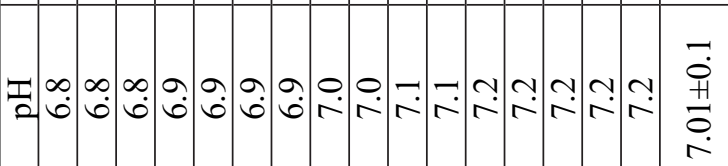

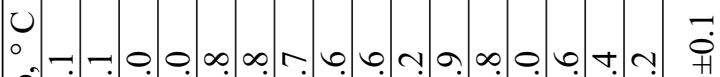

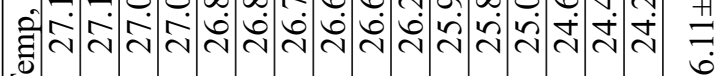
包s

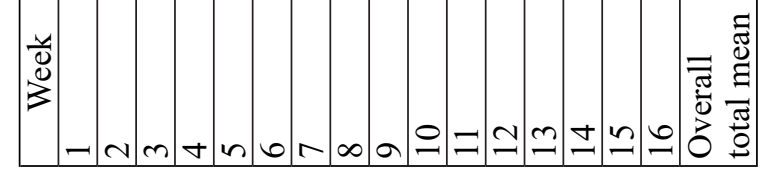

$\frac{\sqrt{3}}{3}$

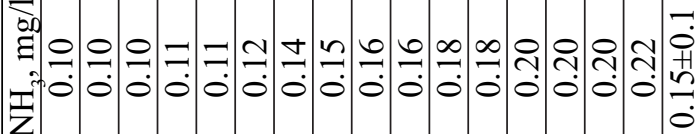

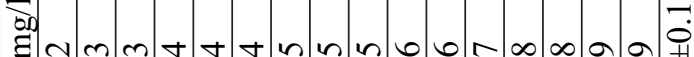

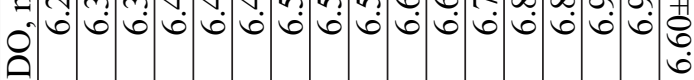

500

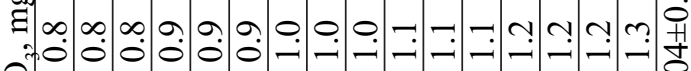
8

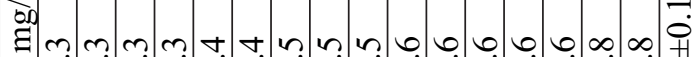

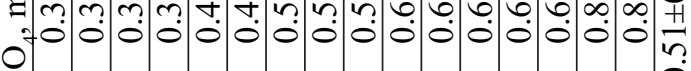
.

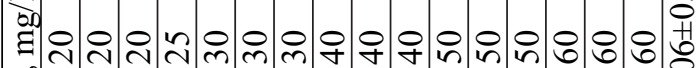

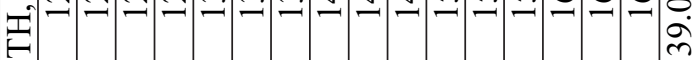

हैं

500

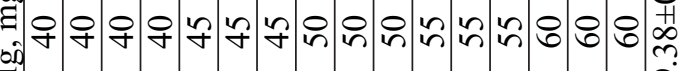

$\sum$

- 10

영

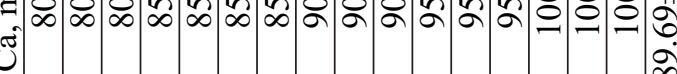

50 s.

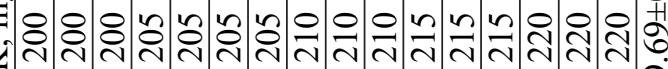

च N

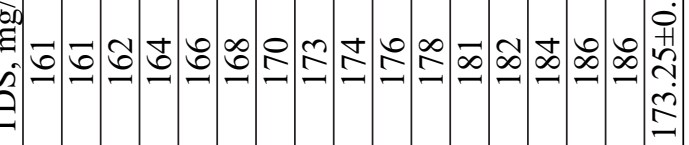

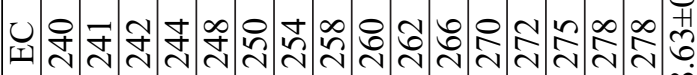

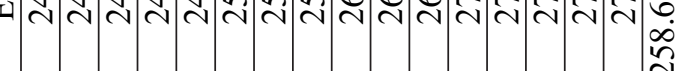

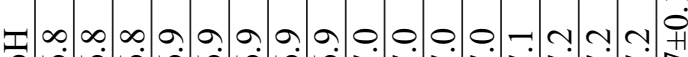
有

u

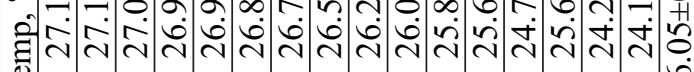
원 
r

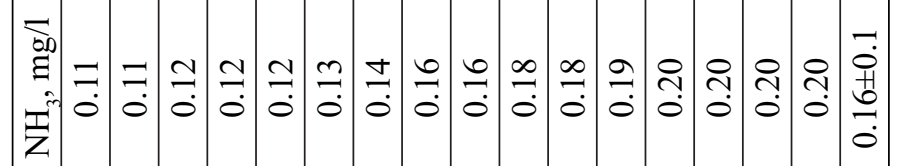

5

ค

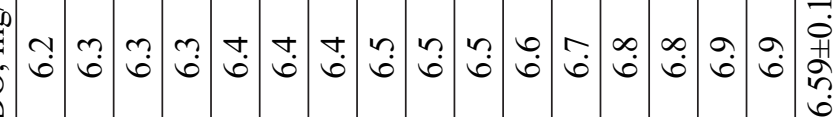

5

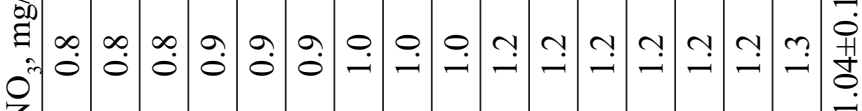

Z

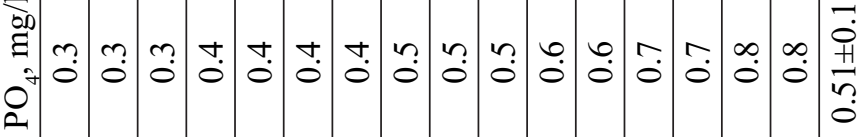

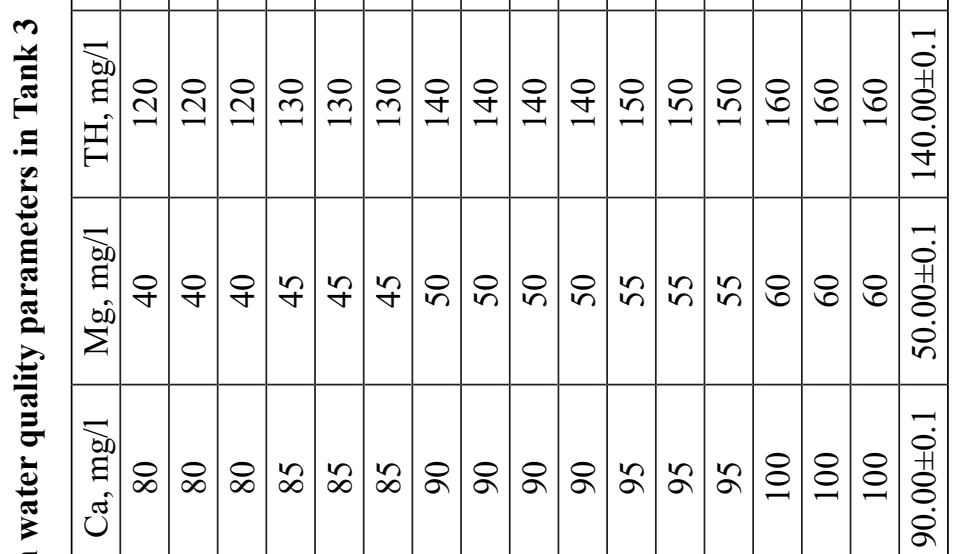

焉

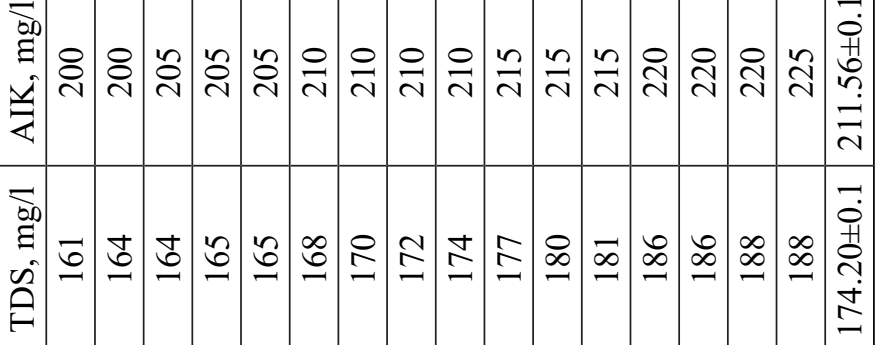

ن

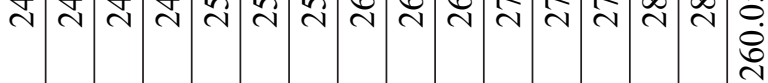

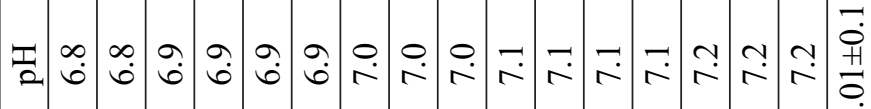

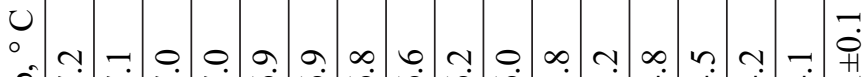

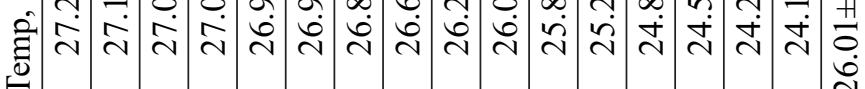

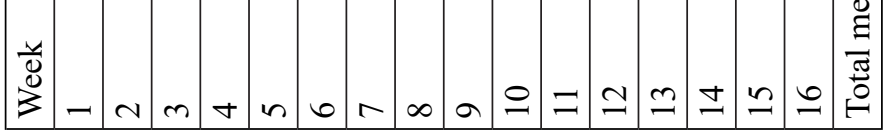

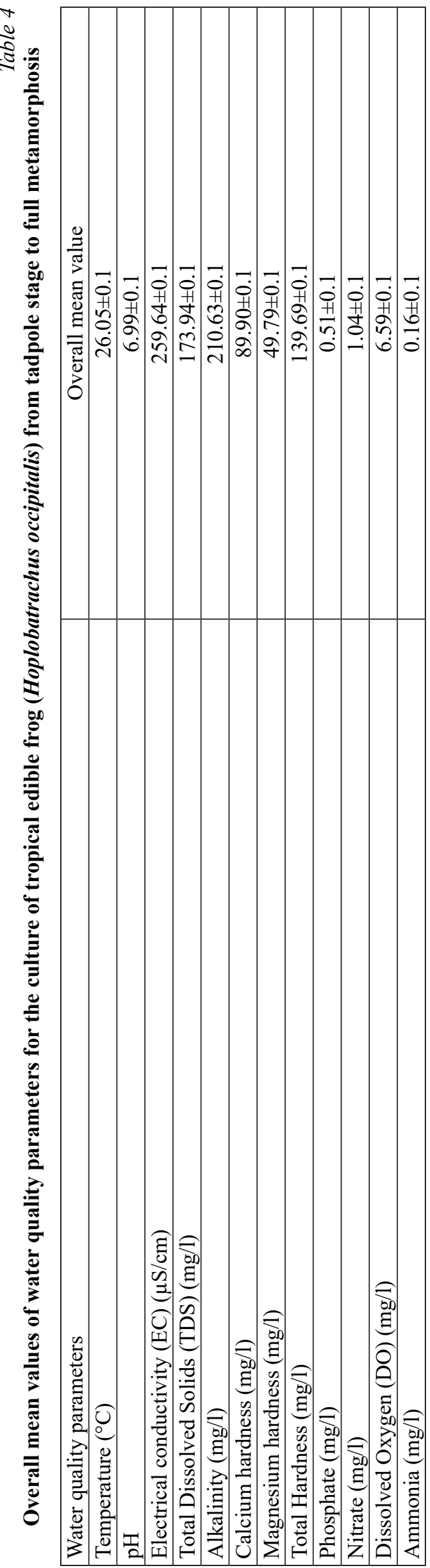


weekly variations in the tanks. The overall mean of the electrical conductivity measurements in the 3 tanks was $259.64 \mu \mathrm{S} / \mathrm{cm}$. Total Dissolved Solids (TDS) varied between a minimum of $161 \mathrm{mg} / \mathrm{l} \mathrm{re-}$ corded in week 1 in all the tanks and maximum of $188 \mathrm{mg} / \mathrm{l}$ recorded in week 16 in tanks 1 and 3 respectively. There was no significant differences $(\mathrm{P}>0.05)$ in the variations of TDS in the 3 tanks, but, there was significant differences $(\mathrm{P}<0.05)$ in weekly variations in TDS among the tanks. The overall mean of the total dissolved solids measurements in the 3 tanks was $173.94 \mathrm{mg} / \mathrm{l}$. The electrical conductivity and total dissolved solids which were positively correlated were in the ranges optimal for Hoplobatrachus occipitalis production in tropical artificial conditions. The high conductivity and total dissolved solids in the ponds probably came from the ground water which was the source of water for the ponds, and the effects of residual feed in water which on decomposition added some mineral salts and suspended particles into the water. [18] had reported that aquafeeds promote increase of ions and suspended particles in culture ponds. [12] reported that high conductivity water supports frog breeding. [2] recommended a conductivity value of $249 \mu \mathrm{S} / \mathrm{cm}$ for Bull frog culture. Mean conductivity of $259.64 \mu \mathrm{S} / \mathrm{cm}$ and mean TDS of $173.94 \mathrm{mg} / 1$ will be the most ideal water quality values for the culture of tropical edible frog Hoplobatrachus occipitalis.

Tank 3 recorded the highest alkalinity measurement of $225 \mathrm{mg} / \mathrm{l}$ in week 16 and lowest of $200 \mathrm{mg} / \mathrm{l}$ of alkalinity was measured in week 1 in all the tanks. There was no significant difference $(\mathrm{P}>0.05)$ in the variations of alkalinity in the 3 tanks, but, there was significant differences $(\mathrm{P}<0.05)$ in weekly variations in the tanks. The overall mean alkalinity recorded in the 3 tanks was $210.63 \mathrm{mg} / 1$. The flow through system of culture which allowed frequent change of water and the source (ground) water used for culture may be responsible for the high alkalinity. In spite of the high alkalinity, the frogs were able to survive, fully metamorphosis and grow in the tanks. This showed that alkalinity ranges of $200-225 \mathrm{mg} / \mathrm{l}$ could be recommended for the culture of edible tropical frog Hoplobatrachus occipitalis. A positive correlation was noted between hardness and alkalinity. The high alkalinity and total hardness of collapsible and concrete ponds allowed for good buffering capacity of the tanks thereby making the tanks to be slightly alkaline.

Calcium, magnesium and total hardness of the tanks were in the ranges of $80-100 \mathrm{mg} / \mathrm{l}$, 40-60 mg/l and 120-160 mg/l, respectively. All the three factors recorded the lowest and highest concentrations in week 1 and 16 in all the tanks, respectively. No significant difference $(\mathrm{P}>0.05)$ was found in the concentrations of the three factors among the tanks; however there was a significant difference $(\mathrm{P}<0.05)$ in the concentrations among the weeks. The overall mean of calcium, magnesium and total hardness was found to be $89.90 \mathrm{mg} / \mathrm{l}$, $49.79 \mathrm{mg} / \mathrm{l}$ and $139.69 \mathrm{mg} / \mathrm{l}$ respectively. Soft to moderate hardness water is good for the breeding of Hoplobatrachus occipitalis. This is evident from the ranges of the calcium, magnesium and total hardness recorded in the 3 tanks. The conductivity and TDS ranges of the ponds also supported the soft to moderate hardness of the tanks for the species breeding. The total hardness values $(120$ $160 \mathrm{mg} / \mathrm{l}$ ) for the breeding of Hoplobatrachus occipitalis in tropical aquaculture was however higher than the range of 10-80 $\mathrm{mg} / 1$ recommended [7].

Phosphate and nitrate varied between $0.3-$ $0.8 \mathrm{mg} / \mathrm{l}$ and $0.8-1.3 \mathrm{mg} / \mathrm{l}$ in all the tanks. The concentrations of the two ions increased with weeks with the lowest found in week 1 and highest in week 16. There was no significance difference $(\mathrm{P}>0.05)$ in the concentrations of the two ions spatially, but significant difference $(\mathrm{P}<0.05)$ exists temporally in the tanks among the two ions. The overall mean of phosphate and nitrate in the tanks was 0.51 and $1.04 \mathrm{mg} / \mathrm{l}$. Phosphate and nitrate levels of $<1.0 \mathrm{mg} / \mathrm{l}$ are desirable and recommended for the culture of Hoplobatrachus occipitalis. High nitrogen and phosphorus concentrations can alter the feeding activity, mobility and reduce the growth and development processes of amphibian larvae [1]. The phosphate and nitrate levels in this study were similar to the results of $[3,13]$ on Bullfrog tadpoles.

The highest dissolved oxygen concentration of $6.9 \mathrm{mg} / \mathrm{l}$ was recorded in all the 3 tanks in week 16 , while the lowest of $6.2 \mathrm{mg} / \mathrm{l}$ was recorded in week 1 also in all the tanks. There was no significant difference $(\mathrm{P}>0.05)$ in the concentration of dissolved oxygen among the tanks and in the weeks. 
The overall mean of dissolved oxygen concentration in the tanks was $6.59 \mathrm{mg} / \mathrm{l}$. Metamorphosising tadpoles require enough dissolved oxygen which they extract from the water through their gills. It is therefore imperative that water for the breeding of frogs should contain enough dissolved oxygen. Dissolved oxygen values recorded in this work could be described as ideal and recommended for the culture of edible tropical frog Hoplobatrachus occipitalis. These values were also similar to the values recorded by [3]. CONAMA Resolution 357/2005 [5] recommends that the minimum limit for dissolved oxygen in frog culture should be $5 \mathrm{mg} / 1$.

Ammonia varied between the lowest concentration of $0.10 \mathrm{mg} / \mathrm{l}$ found in tank 2 in week 1 and highest of $0.22 \mathrm{mg} / 1$ recorded in week 16 also in tank 2. There was no significant difference $(\mathrm{P}>0.05)$ in the concentration of ammonia among the tanks and in the weeks. The overall mean ammonia concentration in the tanks was $0.16 \mathrm{mg} / \mathrm{l}$. Ammonia concentration in the tanks was expected to be high due to the artificial feed used.

The efficient water renewal on the account of the flow through system employed in the culture which promoted dilution and nitrification of the ammonia produced was responsible for the lower concentrations of ammonia recorded in the tanks.

The range of ammonia recorded in the tanks was lower than that reported by $[3,13]$, but was in the range recommended by Ferreira [7]. Thus a range of $0.1-0.25 \mathrm{mg} / \mathrm{l}$ of ammonia in tanks is recommended as the water quality value for successful culture of Hoplobatrachus occipitalis.

The similarity in the range of water quality found in the 3 tanks was due to source (borehole/ ground water) used for the frog culture, the quality and quantity of food used for the rearing as well as the amount of excreted wastes generated into the tanks by the frogs. All these were responsible for the insignificant differences recorded in the parameters among the 3 tanks. The significant differences observed in the temporal variations in the water quality parameters in the tanks was as a result of seasons as seen in the temperature measurements where week 1 was in the dry season with high temperature and week 16 was in the rainy season with low temperature. Similarly, metabolic activities, food intake and utilization, wastes generated into the tanks by the frogs as well as synergistic effects of the parameters on one another may have brought about the significant differences seen in the 16 weeks of culture.

Metamorphosis was deemed to be completed when $99.99 \%$ of the frogs in the tanks have their gills and tail disappeared, mouth widens, eyes bulged while lungs, fore and hind limbs developed.

This work is one of the first to document and establish ranges of water quality factors for the breeding of tropical edible frog (Hoplobatrachus occipitalis) from tadpole stage to full metamorphosis in laboratory experimental tanks. The ranges recorded in the water quality parameters in the tanks could be described as good for the rearing of the species in farm ponds. This is because of the full metamorphosis of the frog and the low (10\%) mortality rate recorded in the tanks.

\section{Conclusion}

The success of edible frog culture such as Hoplobatrachus occipitalis from the tadpole stage depends to a large extent on the good water quality in the culture tanks. This research work has highlighted various water quality parameters and recommended range of values for successful culture of tropical edible frog Hoplobatrachus occipitalis. Ground (borehole) water which was free of pollution and a flow through system in the culture of the species which ensures efficient water renewal should be also employed as it helps in achieving and sustaining a good water quality in the frog ponds culture system.

Perspectives for further future researches. More physic-chemical factors aside from the ones studied in this research should be investigated for the culture of Hoplobatrachus occipitalis including the effects of water containing heavy metals on the biology of the organism.

1. Bishop C., Mahony N., Struger J., Ng P., Petit K. E. Anuran development, density, and diversity in relation to agricultural activity in the Holland River watershed, Ontario, Canada (1990-1992). Environmental Monitoring Assessment, 2008, vol. 57, issue 1, pp. 2143. DOI: $10.1023 / \mathrm{A}: 1005988611661$.

2. Borges F. F., Amaral L. A., De Stéfani M. V. Characterization of effluents from bullfrog (Lithobates catesbeianus, Shaw, 1802) grow-out ponds. Acta Lim- 
nologica Brasiliensia, 2012, vol. 24, no. 2, pp. 160-166. DOI: 10.1590/S2179-975X2012005000035.

3. Borges F. F., De Stéfani M. V. Amaral L. A. Quality of the effluents of bullfrog tadpole ponds. Bol. Inst. Pesca, 2014, vol. 40, no. 3, pp. 409-417.

4. Boyer R., Grue C. E. The need for water quality criteria for frogs. Environmental Health Perspectives, 1995, vol. 103, no. 4, pp. 352-357. DOI: 10.1289/ehp.95103352.

5. Brasil. Dispõe sobre a classificação dos corpos de água e diretrizes ambientais para o seu enquadramento, bem como estabelece as condições e padrões de lançamento de efluentes, e dá outras providências. Diário Oficial da União, 2005, vol. 53, no. 1, pp. 58-63. (in Portuguese)

6. Castro J. C., Pinto A. T. Qualidade da água em tanques de girinos de rã-touro, Rana catesbeiana Shaw, 1802, cultivados em diferentes densidades de estocagem. Revista Brasileira de Zootecnia, 2000, vol. 29, no. 6, suplemento 1, pp. 1903-1911. (in Portuguese)

7. Ferreira C. M. A importância da água e sua utilização em ranários comerciais. Panorama da Aquicultura, 2003, vol. 13, no. 79, pp. 15-17. (in Portuguese)

8. Ferreira C. M., Pimenta A. G. C., Paiva Neto J. S. Introdução à ranicultura. Boletim Técnico do Instituto de Pesca, 2002, vol. 33, p. 15. (in Portuguese)

9. Flores-Nava A. Bullfrog farming: Comparison of inundated and semi dry ongoing methods. Global Aquaculture Alliance, 2000, vol. 1 no. 1, pp. 52-54.

10. Flores-Nava A., Vera-Muñoz P. Growth, metamorphosis and feeding behaviour of Rana catesbeiana Shaw, 1802 tadpoles at different rearing densities. Aquaculture Research, 1999, vol. 30, issue 5, pp. 341-347. DOI: 10.1046/j.1365-2109.1999.00335.x.
11. Helfrich L. A., Neves R. J., Parkhurst J. Commercial frog farming. Virginia Cooperative Extension. Virginia State University, USA, 2001, p. 4.

12. Klaver R. W., Peterson C. R., Patla D. A. Influence of water conductivity on amphibian occupancy in the greater yellow stone ecosystem. Western North American Naturalist, 2013, vol. 73, no. 2, pp. 184-197. DOI: 10.3398/064.073.0208.

13. Mercante C. T. J., Vaz-dos-Santos A. M., Moraes M. A. P., Pereira J. T., Lombardi J. V. Bullfrog (Lithobates catesbeianus) farming system: water quality and environmental changes. Acta Limnologica Brasiliensia, 2014, vol. 26, no. 1, pp. 9-11. DOI: 10.1590/S2179-975X2014000100003.

14. Oza G. M. Ecological effects of the frog's legs trade. The Environmentalist, 1990, vol. 10, issue 1, pp. 39-42. DOI: 10.1007/BF02239556.

15. SAS Institute, Inc. SAS Statistical Software, V.9.2. 2008. SAS Institute, Inc. Cary, North Carolina.

16. Sipaúba-Tavares L. H., Morais J. C. L., De Stéfani M. V. Comportamento alimentar e qualidade de água em tanques de criação de girinos de rã-touro Lithobates catesbeianus. Acta Scientiarum Animal Science, 2008, vol. 30, pp. 95-101. (in Portuguese)

17. Standard Methods for the Examination of $\mathrm{Wa}$ ter and Wastewater. APHA. 22 ${ }^{\text {nd }}$ ed. American Public Health Association, Washington, 2012.

18. Tacon A. G. J., Forster I. P. Aquafeeds and the environment: policy implications. Aquaculture, 2003, vol. 226, issue 1-4, pp. 181-189. DOI: 10.1016/S00448486(03)00476-9. 